\title{
In silico Molecular Docking and Design of Anti-Hepatitis B Drugs
}

\author{
Mahira Arooj ${ }^{1}$, Madiha Sattar ${ }^{1}$, Muniba Safdar ${ }^{1}$, Saima Kalsoom², Shaheen \\ Shahzad*1 \\ ${ }^{1}$ Department of Bioinformatics and Biotechnology, International Islamic University, Islamabad, Pakistan \\ ${ }^{2}$ Department of Chemistry, Quaid-i-Azam University, Islamabad, Pakistan
}

\begin{abstract}
Hepatitis $B$ is a serious health risk nowadays and needs advancement in its treatment against increasing problems of fewer efficacies of drugs and the existence of resistant mutants of hepatitis $B$ virus $(H B V)$. In the present study the problem of designing an anti-Hepatitis $B$ drug with more efficacies was solved by using computer aided drug designing (CADD). Docking of 30 selected ligands, comprised of active drugs for hepatitis B and compounds having anti-Hepatitis B activity, was done with the active site of protein GIPC2 and a lead compound was recognized on the basis of hydrogen bonding, hydrophobic and ionic interactions. A Quantitative structure activity relationship of selected 30 compounds was also performed in which electronic and steric descriptors were calculated and correlated with the bioactivity (IC50) of the drugs. Three analogs of the lead compound were designed to enhance its activity against hepatitis $B$ virus $(H B V)$. Analogs were docked with protein GIPC2 and their interactions showed that they could possess good inhibitory activity against $H B V$ with suitable drug-like properties as compared to other active drugs for hepatitis $B$ and therefore could be recommended for further studies.
\end{abstract}

Keywords: Analog, anti-hepatitis B drugs, antiviral agents, anti HBV drugs, computer aided drug design, IC50, molecular docking, lead compound, QSAR

Abbreviations: ${ }^{\circ} A$ : Angstrom; CADD: Computer Aided Drug Design; 3D: 3 dimensional; $\quad$ DNA: Deoxyribonucleic acid; EHOMO: Higher occupied molecular orbital energy; ELUMO: Lowest unoccupied molecular orbital energy; ETOTAL: Total binding energy; HBeAG: Hepatitis B "e" antigen; HBsAG: Hepatitis $B$ "s" antigen; HBV: Hepatitis B Virus; IC50: Half inhibitory concentration; LogP: Hydrophobicity; MR: Molar refractivity; Mw: Molecular weight; QSAR: Quantitative structure-activity relationship; Vm: Molar volume; VMD: Visual molecular dynamics.

\section{Introduction}

Hepatitis B virus (HBV) infection is a worldwide health problem and may lead to lifelong infection, cirrhosis of the liver, liver cancer, liver failure, and death. It is most prevalent in Asia, Africa, Southern Europe and Latin America, where the prevalence of hepatitis B surface antigen (HBsAg) carriers in the general population ranges from $2 \%$ to $20 \%$ [1]. Although vaccination programs are implemented in various countries, but it is still affecting 350 million to 400 million people worldwide [2]. In Pakistan, there are estimated to be 7-9 million carriers of hepatitis B virus (HBV) with a carrier rate of 3-5\% with infection rate rising steadily [3].

Hepatitis B virus (HBV) is the prototype member of the Hepadnaviridae (hepatotropic DNA virus) family. It has eight genotypic classes, A to $\mathrm{H}$ each having a distinct geographic distribution [4]. The only known host for HBV, so far, is human, although some non-human primates have been infected in laboratory conditions [5].

The goal of hepatitis B treatment is to prevent the serious infections like cirrhosis, liver decompensation and hepatocellular carcinoma. In clinical practice, treatment response is determined by suppression of serum HBV DNA levels, hepatitis B e antigen (HBeAG) seroconversion to hepatitis B e antibody, hepatitis B surface antigen (HBsAG) loss, normalization of alanine aminotransferase levels and improvement in liver histology [6].

Currently available treatment agents include the immunomodulatory drugs IFN- $\alpha$ and peginterferon, as well as several antiviral nucleotide/ nucleoside agents: lamivudine, telbivudine, adefovir, entecavir, and tenofovir. Over the last years, the field of CHB treatment has seen an expansion of long-term data on several of these agents, both when used as monotherapy and when used in combination [7]. Antiviral drug resistance is a significant factor in determining the success of long-term therapy for chronic hepatitis B. In the future, novel therapeutic targets or creative combination therapies are required in order to increase the rates of sustained responses after treatment discontinuation. In addition, new research efforts are needed to identify therapeutic approaches that would be able to achieve HBV eradication or at least HBsAg loss and seroconversion in a sizeable proportion of patients [8].

The present work aimed at the in silico development and design of an anti-hepatitis B virus (HBV) drug against a protein target, as the leading drug for the hepatitis B treatment. In silico methods can help in 
identifying drug targets via bioinformatics tools.Modern drug discovery has given rise to the field known as computer-aided drug design (CADD). It represents computational methods and resources that are used for facilitating the design and discovery of new therapeutic compounds [9]. The main objective of CADD is to speed-up the screening process, focused and target directed screening and failing drugs fast by removing the hopeless ones, as soon as possible, and hence screening efficiently.

Computer-aided drug design, involves the use of biochemical information of ligand-receptor interaction in order to postulate ligand refinements. The best possible starting point is an X-ray crystal structure of the target site. If the molecular model of the building site is precise enough, one can apply docking algorithms that simulate the building of drugs to the respective receptor site [10]. The whole drug designing scheme, is illustrated in Fig.1.

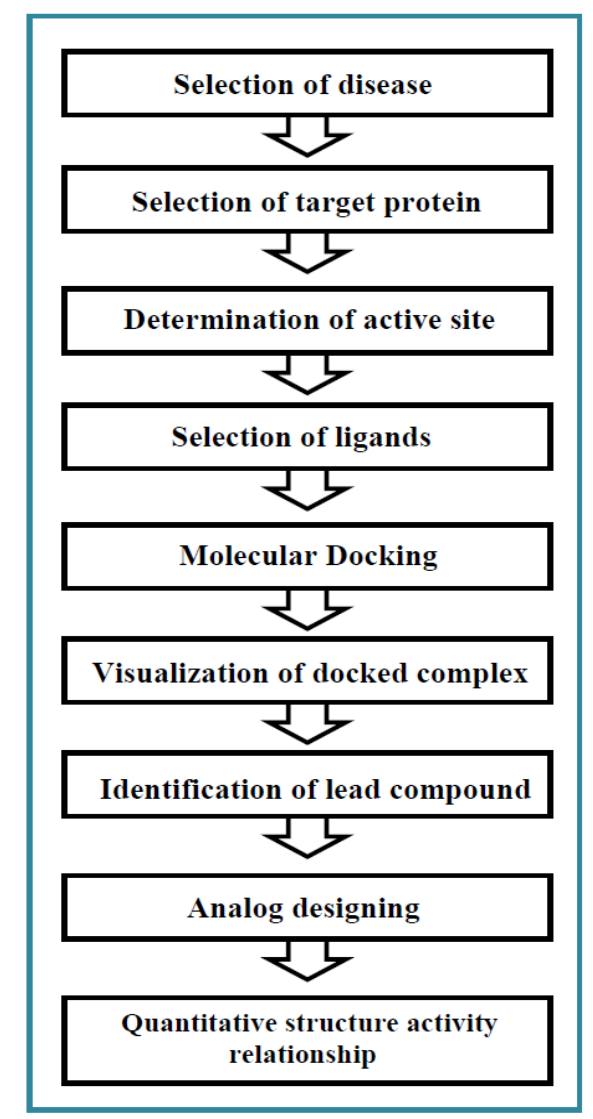

Figure 1. Drug designing scheme.

The main purpose was to suggest some compounds as anti-hepatitis B inhibitors by using molecular docking studies on the basis of high binding interactions and low binding energies. Molecular docking plays an important role in drug designing by placing a ligand molecule into the binding site of the target molecule in a non-covalent fashion [11]. Flexible docking programs like DOCK [12], Molecular Operating Environment (MOE), and AutoDock [13] enable user to predict favorable biological target-ligand complex structures with reasonable accuracy and speed. The docked complex is then visualized and studied using software like VMD (Visual Molecular Dynamics) [14].

Compounds suggested through molecular docking were tested for bioactivity, on the basis of quantitative structure activity relationship (QSAR). These studies were carried out to identify an effective, selective and efficient anti hepatitis B agent [15]. The quantitative structure- activity relationship (QSAR) studies are of immense importance. Along with providing guidelines for the drug design, QSAR also sheds light on the mechanisms of drug-receptor interactions, which further assist to the rationalization of drug development. We, therefore, present here a QSAR study selected anti HBV compounds [16]. Different software such as ChemDraw[17], HyperChem [18], AutoDock [13] and VMD [14] were selected and used to get the results. 


\subsection{Target selection}

\section{Methodology}

Identifying and selecting the most appropriate drug target or receptor is the initial step in the drug designing procedure. Excellent drug targets can be identified with the help of bioinformatics. For a drug target to be ideal, it must be linked closely to the selected human disease. Mostly proteins act as good targets for the drugs. In some cases, enzymes can also serve as excellent drug targets [19].Recently identified PDZ domain containing protein GIPC2 (Protein Data Bank ID: 3GGE), having human source, was chosen as target protein for the present study, as shown in Fig.2.

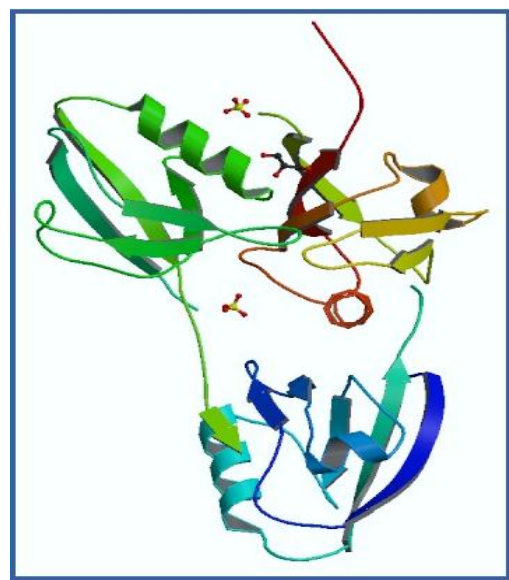

Figure 2 Crystal structure of PDZ domain containing protein GIPC2.

Once target is identified, the candidate ligands can be selected from already known drugs having appropriate anti HBV effects.

\subsection{Ligand selection}

Several anti-hepatitis B compounds or HBV inhibitors were identified and selected. These included 30 compounds with drug like properties against hepatitis B. Along with selected compounds including market drugs as well as drugs under clinical trials, 2 approved and standard anti-hepatitis B drugs adefovir and lamivudine were also chosen. The structures and IC50 values of these 30 compounds including 3 standard drugs are shown in Table 1 [1,20-34]. These drugs were selected through the study and evaluation of past and present research on anti-hepatitis B virus (HBV) agents according to their efficacy against the infection and less IC50 (half inhibitory concentration) value.

\subsection{Molecular Docking}

It gives the active conformation of ligand with target protein. The structures of 30 selected compounds were drawn using ChemDraw tool. AutoDock was used to predict the binding modes of 30 selected compounds with the active site of the target protein GIPC2. AutoDock will try a set of different conformers of the ligand in order to obtain the best disposition of the atoms of the molecule for maximizing the scoring function that quantifies ligand-receptor interaction [10].

The structure of target protein GIPC2 was obtained from Protein Data Bank (Protein Data Bank ID: 3GGE).For using the receptor or target protein in the AutoDock, all the missing side chain atoms were checked and then repaired and also hydrogen atoms were added using the graphical user interface of AutoDocktools (ADT) [35]. Before the docking experiment water molecules were removed. Then ligand was taken as input and gasteiger charges [36] were calculated. The nonpolar hydrogens were merged to carbon atoms and AutoDock type was assigned to each atom, preparing the docking input files of ligands. The torsions were chosen to make certain bond types active (rotatable) or inactive (non-rotatable) and numbers of torsions were then set to most atoms. 
In silico Molecular Docking and Design of Anti-Hepatitis B Drugs

Table 1 . Chemical structure and IC50 of selected compounds.

\begin{tabular}{|c|c|c|c|c|c|c|c|}
\hline No & Name & Structure & $\begin{array}{l}\mathrm{IC}_{50 \mathrm{u}} \\
\mathrm{MI}\end{array}$ & $\mathrm{N}_{0}$ & Name & Structure & $\begin{array}{l}\mathrm{IC}_{50 \mathrm{u}} \mathrm{u} \\
\mathrm{M}\end{array}$ \\
\hline 1 & Helioxanthin & & 1 & 9 & $\begin{array}{l}2-\{2-[1-(4-n i t r o- \\
\text { benzenesulfonyl)-1H- } \\
\text { benzoimidazol-2-y1]- } \\
\text { ethyl\}-isoindole- } 1,3- \\
\text { dione }\end{array}$ & & 14.2 \\
\hline 2 & Helioxanthin analog 1-8 & & 0.1 & 10 & $\begin{array}{l}\text { ClevudineD- } \\
\text { enantiomer(D-FMAU) }\end{array}$ & & 50 \\
\hline 3 & $\begin{array}{l}\text { Helioxanthin analog 5-4- } \\
2\end{array}$ & & 0.08 & 11 & Adefovirdipivoxil & & 0.01 \\
\hline 4 & Triterpenoidsaponin & & 19.45 & 12 & Entecavir & & 0.0016 \\
\hline 5 & BAY 41-4109 & & 0.053 & 13 & Lamivudine & & 0.1 \\
\hline 6 & $\begin{array}{l}\text { 9-oxadecyl-6-methyl- } \\
\text { DGJ(nonyldeoxy- } \\
\text { galactonojirimycin) }\end{array}$ & & 4.6 & 14 & $\begin{array}{l}\text { 2-(2-(5,6-dichloro-1- } \\
\text { methyl-1H- } \\
\text { benzo[d]imidazol-2- } \\
\text { yl)ethyl)isoindoline- } \\
\text { 1,3-dione }\end{array}$ & & 0.9 \\
\hline 7 & $\begin{array}{l}\text { 10-Methoxy-2-methyl-8- } \\
\text { (morpholinomethyl)-6H- } \\
\text { [1]benzothiopyrano[4,3- } \\
\text { b]quinolin-9-01 }\end{array}$ & & 14.7 & 15 & Telbivudine & & 0.19 \\
\hline 8 & Emtricitabine & & 0.025 & 16 & Beta-L-D4A & & 0.61 \\
\hline
\end{tabular}




\begin{tabular}{|l|l|l|l|l|l|l|}
\hline No & \multicolumn{1}{|c|}{$\begin{array}{l}\text { Name } \\
17\end{array}$} & $\begin{array}{l}\text { IC50 } \\
\text { uM }\end{array}$ & No & Name & IC50 \\
uM \\
fumarate
\end{tabular}

Autogrid calculations were done which define the search grid and produce grid maps used later by AutoDock. Grid properties were then set by setting the grid dimensions, spacing, and center in the grid box at $60 \times 60 \times 60 \AA$ grid points using autogrid.

The docking parameter file was then prepared by specifying rigid molecule, for rigid docking. Then the ligand was specified. The search parameters were set using Lamarckian genetic algorithm and also the docking parameters were set to default, for molecular docking. For all ligands, ten different docking conformations were obtained. The lowest energy conformation of each ligand was selected as the active conformation, among all the observed conformations, and was then analyzed.

The active conformation of each ligand and the target protein were given as an input to the Visual Molecular Dynamics (VMD), to predict and study the ligand-protein interactions. The amino acids present within $5^{\circ} \mathrm{A}$ of active site of target protein were selected and then binding interactions were identified between the ligand and active site of the target protein. The binding interactions of selected 30 ligands, including standard ones, were identified.

The compound exhibiting the best binding interactions of all was identified as Lead compound. It is a chemical compound having biological activity and its chemical structure is used as a starting point for 
chemically modifying the drugs in order to improve the potency or selectivity. Lead identification is the most critical stage in drug discovery and designing [19].

\subsection{Analog designing}

After the identification of Lead compound, its three structural analogs were prepared by introduction or elimination of functional groups in the lead compound and were studied with the help of AutoDock. Binding interactions of each analog and target molecule were also identified. The analog of an existing drug molecule shares structural and pharmacological similarities with the lead compound. They are designed to extract new drugs from the existing ones to make them legally available in the market.

\subsection{Quantitative structure activity relationship (QSAR)}

QSAR correlates structural or property descriptors of compounds with their activities. To get an insight into the structure-activity relationship molecular descriptors are needed that can effectively characterize molecular size, molecular branching or the variations in molecular shapes, and can influence the structure and its activities [37]. It is very essential in drug discovery and design.

A quantitative structure activity relationship was interpreted by calculating a number of electronic and steric parameters. Different steric descriptors like molar Refractivity (MR) and partition coefficient (log P) and electronic descriptors ELUMO (lower unoccupied molecular orbital energy), EHOMO (higher occupied molecular orbital energy) and Total binding energy of the ligand (ETOTAL), were found to prove that these selected anti-hepatitis B compounds exhibit drug like properties. ChemDraw was used to find molar volume, molecular weight, $\log \mathrm{P}$ and molar refractivity while HyperChem was used to find ETOTAL, ELUMO and EHOMO.

\section{Results and Discussion}

\subsection{Molecular Docking of anti-hepatitis $B$ compounds}

A usually smaller molecule which binds to a larger molecule such as enzyme or protein initiates the metabolic process. On the basis of docking of test set compounds and standard anti-hepatitis B drugs with the protein, the GIPC2 was searched for its active site. The active site within protein GIPC2, depicted in Fig.3A. The most common amino acids of active site were shown in Fig.3B.

On the basis of docking, the amino acids within $5^{\circ} \mathrm{A}$ i.e. the active site, were identified. The amino acids within $5^{\circ} \mathrm{A}$ around the ligands are listed in Table 2 . The residues found within $5^{\circ} \mathrm{A}$ of active site of GIPC2 were ASN169, ILE196, SER-1, GLY113, PRO198, VAL171, TRP173, LYS112, TYR138, GLU168, ASP133, HIS161, ARG174, ALA179, THR132, and PHE140. The study revealed that LYS112, VAL171, GLY113 and GLU168 were major determinants of binding. Then docking calculations were carried out using GIPC2 target protein and the test set compounds listed in Table 1.

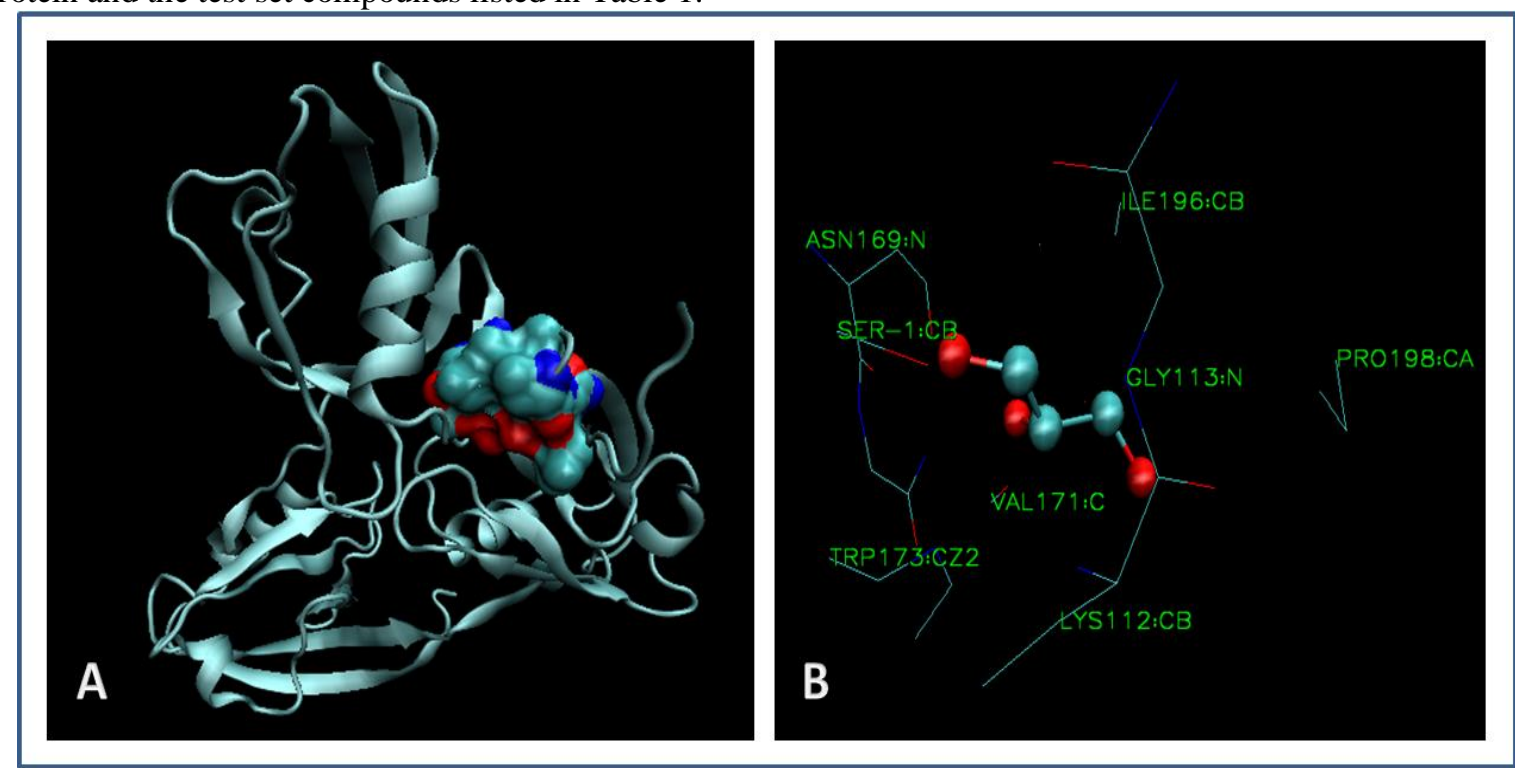

Figure 3 (A) GIPC2 Protein represented in new cartoon style and the active site within represented as surf style. (B) Active site of GIPC2 showing the residues within $5^{\circ} \mathrm{A}$. 

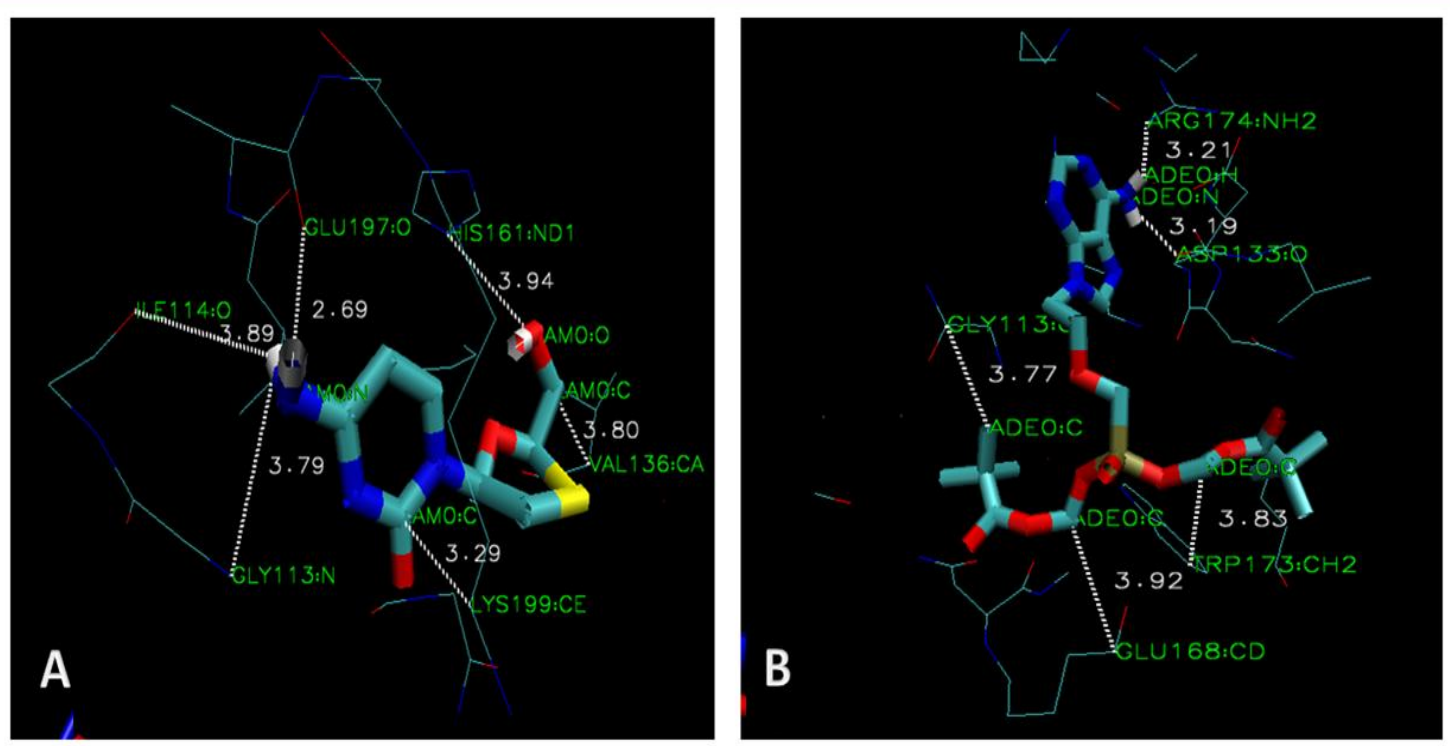

Figure 4 (A) Predicted interactions of lamivudine with the active site of GIPC2. (B) Predicted interactions of adefovir with the active site of GIPC2.

Among the standard drugs, lamivudine and adefovir were selected for docking with the protein GIPC2. The ability of the ligand to bind the active site of target within $5^{\circ} \mathrm{A}$ was measured. The hydrogen, hydrophobic and ionic interactions of the standard drug lamivudine shown in Fig.4A and the interactions of standard drug adefovir illustrated in Fig.4B. Keeping in view the interactions, lamivudine had better efficacy than adefovir. Once all the test set compounds were docked, VMD was used to get the interactions i.e., hydrogen bonding, ionic bonding and hydrophobic interactions, shown in Table 3.

\subsection{Lead compound identification}

On the basis of binding interactions of the test set compounds, one lead compound was figured out. The information in Table 3 showed that compounds 2, 4, 13, 18, had good hydrogen and ionic bondings with the amino acids within the $5^{\circ} \mathrm{A}$ of active site of GIPC2.

According to the binding interactions of these four compounds and IC50 values, compound 2 (Helioxanthin analog 1-8) was considered as the lead compound. Fig.5A shows the hydrogen bonds of the lead compound with the amino acids within the active site of GIPC2, while Fig.5B shows the hydrophobic interactions. 
Table 2: Contacts in the sphere of $5^{\circ} \mathrm{A}$ radius around the ligands. The presence or absence of contacts is represented with (+) or (-) and are included for comparison with lamivudine and adefovir standard drugs

\begin{tabular}{|c|c|c|c|c|c|c|c|c|c|c|c|c|c|c|}
\hline No & $\begin{array}{l}\text { Arg } \\
174 \\
\end{array}$ & $\begin{array}{l}\text { Asn } \\
169\end{array}$ & $\begin{array}{l}\text { Asp } \\
133 \\
\end{array}$ & $\begin{array}{l}\text { Gly } \\
113 \\
\end{array}$ & $\begin{array}{l}\text { Glu } \\
168\end{array}$ & $\begin{array}{l}\text { His } \\
161 \\
\end{array}$ & $\begin{array}{c}\text { Ile } \\
196\end{array}$ & $\begin{array}{l}\text { Lys } \\
112\end{array}$ & $\begin{array}{l}\text { Phe } \\
140\end{array}$ & $\begin{array}{l}\text { Pro } \\
198 \\
\end{array}$ & $\begin{array}{l}\text { Thr } \\
132\end{array}$ & $\begin{array}{l}\text { Trp } \\
173 \\
\end{array}$ & $\begin{array}{l}\text { Tyr } \\
138\end{array}$ & $\begin{array}{l}\text { Val } \\
171 \\
\end{array}$ \\
\hline 1 & - & + & + & + & - & + & + & + & + & - & + & - & + & + \\
\hline 2 & + & + & - & + & - & + & - & + & + & - & + & - & + & + \\
\hline 3 & + & + & + & + & + & + & + & - & + & - & - & - & + & + \\
\hline 4 & + & + & - & + & - & - & + & + & + & - & + & + & + & + \\
\hline 5 & + & + & + & + & - & + & - & + & + & - & + & - & - & + \\
\hline 6 & + & - & - & + & + & + & + & + & - & + & + & + & + & + \\
\hline 7 & + & + & + & + & - & + & - & + & + & - & - & - & + & + \\
\hline 8 & + & + & - & + & + & + & + & + & - & + & + & + & - & + \\
\hline 9 & + & - & + & + & + & + & + & + & + & + & + & - & + & - \\
\hline 10 & + & + & + & + & + & + & + & + & - & - & + & + & - & + \\
\hline 11 & + & - & + & + & - & - & - & + & + & - & + & + & + & + \\
\hline 12 & - & - & - & + & + & + & + & + & - & + & - & + & + & + \\
\hline 13 & - & - & - & + & + & + & + & + & - & + & - & - & + & + \\
\hline 14 & + & + & - & + & + & - & + & + & - & + & - & + & - & + \\
\hline 15 & + & - & - & + & + & + & + & + & + & + & - & + & + & + \\
\hline 16 & - & + & + & + & - & - & - & + & - & - & - & + & - & + \\
\hline 17 & - & - & + & - & - & + & - & - & - & - & - & - & + & + \\
\hline 18 & - & + & - & - & + & - & - & + & - & - & - & - & + & + \\
\hline 19 & + & - & + & + & + & + & + & + & + & - & + & + & + & + \\
\hline 20 & + & + & + & + & - & + & + & + & + & - & - & + & + & + \\
\hline 21 & + & - & + & + & - & + & - & + & - & + & - & + & + & + \\
\hline 22 & + & - & + & + & + & + & + & - & - & + & + & + & + & + \\
\hline 23 & + & + & - & + & + & + & + & + & - & + & - & + & + & + \\
\hline 24 & + & + & + & + & - & - & - & + & + & - & - & + & + & + \\
\hline 25 & + & - & - & + & + & - & + & + & + & + & - & + & + & + \\
\hline 26 & + & - & + & + & + & + & + & + & + & + & + & + & + & + \\
\hline 27 & + & + & + & + & - & - & - & + & + & - & - & + & + & + \\
\hline 28 & - & + & - & + & - & + & + & + & - & + & - & + & + & + \\
\hline 29 & + & + & + & + & + & - & + & - & - & - & - & + & - & + \\
\hline 30 & + & + & + & + & - & + & + & + & + & - & + & + & + & + \\
\hline
\end{tabular}


In silico Molecular Docking and Design of Anti-Hepatitis B Drugs

Table 3. Binding interactions of Test set with amino acids present within $5^{\circ} \mathrm{A}$ radius of target protein.

\begin{tabular}{|c|c|c|c|}
\hline $\begin{array}{l}\text { Compound } \\
\text { No. }\end{array}$ & Hydrogen Bonding & Hydrophobic interactions & Ionic bonding \\
\hline 1 & none & $\begin{array}{l}\text { C - PHE140 [3.41] } \\
\text { C - GLY172 [3.44] } \\
\text { C - VAL136 [3.60] }\end{array}$ & $\begin{array}{l}\text { O - ASN134:ND2[2.64] } \\
\text { O - LYS199:NZ[3.01] }\end{array}$ \\
\hline 2 & NH - LYS142:NZ[3.79] & $\begin{array}{l}\mathrm{C}-\mathrm{VAL136}[3.09] \\
\mathrm{C}-\mathrm{PHE} 140[3.28] \\
\mathrm{C}-\mathrm{GLY} 172[3.30] \\
\mathrm{C}-\mathrm{ARG} 174[3.29] \\
\mathrm{C}-\mathrm{TYR} 138[3.45]\end{array}$ & $\begin{array}{l}\mathrm{O}-\mathrm{ASN} 134: \mathrm{ND} 2[2.65] \\
\mathrm{O}-\mathrm{HIS} 161: \mathrm{ND} 1[3.420] \\
\mathrm{O}-\mathrm{HIS} 161: \mathrm{NE} 2[3.89]\end{array}$ \\
\hline 3 & $\begin{array}{l}\mathrm{NH} \text { - LYS199:NZ[3.34] } \\
\text { O - TYR138:OH[2.77] }\end{array}$ & $\begin{array}{l}\text { C - VAL136 [3.59] } \\
\text { C - ILE196 [3.61] }\end{array}$ & $\mathrm{O}-\mathrm{ARG174:NH[3.42]}$ \\
\hline 4 & $\begin{array}{l}\text { OH - GLY135:O[1.91] } \\
\text { O - ARG143:NH[3.64] }\end{array}$ & $\begin{array}{l}\mathrm{C}-\mathrm{ARG} 174[2.88] \\
\mathrm{C}-\mathrm{PHE} 140[3.00] \\
\mathrm{C}-\mathrm{VAL} 158[3.67]\end{array}$ & $\begin{array}{l}\mathrm{O}-\mathrm{ASN} 134: \mathrm{ND} 2[3.26] \\
\mathrm{O}-\mathrm{VAL} 136: \mathrm{N}[3.428]\end{array}$ \\
\hline 5 & none & $\begin{array}{l}\text { C - THR132 [3.39] } \\
\text { C - VAL158 [3.76] } \\
\text { C - LYS142 [3.79] }\end{array}$ & $\begin{array}{l}\text { O - LYS199:NZ[2.563] } \\
\text { N - GLY172:O[3.687] }\end{array}$ \\
\hline 6 & $\begin{array}{l}\mathrm{OH} \text { - GLY172:N[2.89] } \\
\mathrm{OH} \text { - VAL171:O[1.93] }\end{array}$ & $\begin{array}{c}\mathrm{C}-\mathrm{HIS} 161[3.40] \\
\mathrm{C}-\mathrm{THR} 132[3.60]\end{array}$ & $\begin{array}{l}\text { O - GLY172:N[3.58] } \\
\text { O - LYS199:NZ[3.82] }\end{array}$ \\
\hline 7 & none & $\begin{array}{l}\text { C - PHE140 [3.29] } \\
\text { C - TYR138 [3.39] } \\
\text { C - GLY135 [3.74] }\end{array}$ & O - LYS199:NZ[2.612] \\
\hline 8 & $\begin{array}{c}\mathrm{OH}-\mathrm{TRP} 173: \mathrm{N}[3.60] \\
\mathrm{NH}-\mathrm{VAL136:N} \mathrm{[3.92]} \\
\mathrm{NH}-\mathrm{ARG174:NE}[3.36]\end{array}$ & C-TYR138 [3.39] & $\begin{array}{l}\mathrm{O} \text { - HIS161:NE1[3.94] } \\
\mathrm{N} \text { - GLU197:O[2.69] }\end{array}$ \\
\hline 9 & O - ARG174:NH1[2.64] & $\begin{array}{l}\text { C-TYR138 [3.09] } \\
\text { C-LYS142 [3.10] }\end{array}$ & $\begin{array}{l}\text { O - GLY113:N[3.42] } \\
\text { O - ARG174:NE[3.93] }\end{array}$ \\
\hline 10 & $\begin{array}{l}\mathrm{OH} \text { - VAL136:N[3.90] } \\
\mathrm{OH} \text { - VAL136:O[1.96] }\end{array}$ & $\begin{array}{l}\text { C - VAL171[3.58] } \\
\text { C - GLY172[3.20] } \\
\text { C - LYS199[3.27] }\end{array}$ & O - LYS199:NZ[3.49] \\
\hline 11 & $\begin{array}{c}\text { N - ARG174:NH2[3.79] } \\
\text { NH - LYS200:O[3.90] }\end{array}$ & $\begin{array}{l}\text { C - GLU168[3.92] } \\
\text { C - GLY113[3.77] }\end{array}$ & $\mathrm{N}$ - ASP133:OD1[2.75] \\
\hline 12 & $\mathrm{NH}-\mathrm{THR} 132: \mathrm{OG} 1[2.37]$ & $\begin{array}{l}\mathrm{C}-\mathrm{ARG} 174[2.82] \\
\mathrm{C}-\mathrm{ARG} 174[3.30] \\
\mathrm{C}-\mathrm{PHE} 140[3.34]\end{array}$ & None \\
\hline 13 & $\begin{array}{c}\text { NH - ILE114:O[3.89] } \\
\text { NH - GLY113:N[2.79] }\end{array}$ & $\begin{array}{l}\text { C - LYS199[3.29] } \\
\text { C - VAL136[3.80] } \\
\text { C - ILE196 [3.20] }\end{array}$ & None \\
\hline 14 & none & $\begin{array}{l}\text { C-GLU115[3.19] } \\
\text { C-ILE196[3.37] } \\
\text { C-VAL171[3.14] }\end{array}$ & None \\
\hline 15 & $\begin{array}{l}\text { OH - GLU197:O[2.85] } \\
\text { OH - PRO198:N [3.87] }\end{array}$ & $\begin{array}{l}\text { C-TYR138[3.12] } \\
\text { C-TYR138[3.14] }\end{array}$ & none \\
\hline 16 & $\mathrm{NH}-\mathrm{VAL} 171: \mathrm{O}[2.13]$ & $\begin{array}{l}\text { C-ASP177[3.50] } \\
\text { C-ASN } 134[3.28] \\
\text { C-TRP173[3.01] }\end{array}$ & None \\
\hline
\end{tabular}


In silico Molecular Docking and Design of Anti-Hepatitis B Drugs

\begin{tabular}{|c|c|c|c|}
\hline 17 & $\begin{array}{l}\mathrm{NH}-\mathrm{LYS} 180: \mathrm{N}[3.44] \\
\mathrm{NH}-\mathrm{ALA1} 1 \mathrm{7}: \mathrm{N}[3.82]\end{array}$ & $\begin{array}{l}\text { C - LYS180[3.78] } \\
\text { C - ALA179[3.94] }\end{array}$ & $O-$ LYS180:NZ[2.79] \\
\hline 18 & $\begin{array}{l}N-\text { TYR138:OH[2.74] } \\
N H \text { - GLU163:O[1.96] }\end{array}$ & $\begin{array}{l}\text { C - GLU163 [3.52] } \\
\text { C - LYS } 194[3.42] \\
\text { C - GLU163[3.59] }\end{array}$ & $\begin{array}{l}N-\text { GLU 163:OE2 [2.71] } \\
N \text { - GLU 163:OE2 [2.69] }\end{array}$ \\
\hline 19 & $\begin{array}{l}\text { OH - VAL136:O[2.14] } \\
\text { OH - GLY17 } 2: O[3.55]\end{array}$ & $\begin{array}{l}\text { C - TYR138[3.15] } \\
\text { C - ARG1 } 4 \text { [3.48] }\end{array}$ & None \\
\hline 20 & $\mathrm{OH}-\mathrm{GLY} 172: \mathrm{N}[3.90]$ & $\begin{array}{l}\text { C - PHE140[3.44] } \\
\text { C - PHE140[3.17] } \\
\text { C - ARG174[3.28] }\end{array}$ & None \\
\hline 21 & $\begin{array}{l}\mathrm{OH}-\mathrm{H} I S 161: \mathrm{N}[3.40] \\
\mathrm{OH}-\mathrm{HIS} 161: \mathrm{N}[3.02]\end{array}$ & $\begin{array}{l}\text { C - TYR138[3.15] } \\
\text { C-PHE140[3.19] }\end{array}$ & $O-$ HIS1 $61: N[3.42]$ \\
\hline 22 & $\begin{array}{l}\text { OH - VAL136:O[1.96] } \\
\text { OH - GLY137:O[2.98] }\end{array}$ & $\begin{array}{l}\text { C - TYR138[3.19] } \\
\text { C - LYS199[3.44] } \\
\text { C - ARG174[3.21] }\end{array}$ & None \\
\hline 23 & None & $\begin{array}{l}C \text { - ILE196[3.40] } \\
C \text { - GLY172[3.15] } \\
C \text { - GLU197[3.57] }\end{array}$ & None \\
\hline 24 & None & $\begin{array}{l}\text { C - PHE 140[2.89] } \\
\text { C - ASN134[3.01] } \\
\text { C - TYR138[3.17] }\end{array}$ & $\begin{array}{l}\text { O-ARG174:N[2.83] } \\
\text { O-LYS199:N[3.81] }\end{array}$ \\
\hline 25 & None & $\begin{array}{l}\text { C - ILE196[3.35] } \\
\text { C - LYS199[3.35] } \\
\text { C - PHE140[3.69] }\end{array}$ & None \\
\hline 26 & None & $\begin{array}{c}\text { C - TYR138[2.90] } \\
\text { C-LE196[3.38] } \\
\text { C- PHF14nr3.n51 }\end{array}$ & O- LYS199:N[3.46] \\
\hline 27 & $\begin{array}{l}\mathrm{OH}-\mathrm{GLY} 172: \mathrm{O}[2.00] \\
\mathrm{OH}-\mathrm{GLY} 135: \mathrm{O}[2.05]\end{array}$ & $\begin{array}{l}\text { C-ARG174[3.46] } \\
\text { C-PHE140[3.90] }\end{array}$ & $\begin{array}{l}O \text { - LYS199:N[2.73] } \\
O \text { - LYS199:N[3.19] }\end{array}$ \\
\hline 28 & $\begin{array}{l}\mathrm{OH}-\mathrm{HIS} 161: \mathrm{N}[2.78] \\
\mathrm{OH}-\mathrm{GLY} 172: \mathrm{O}[2.37]\end{array}$ & $\begin{array}{l}\text { C - ILE196[3.53] } \\
\text { C - VAL171 [3.92] } \\
C \text { - TYR138[3.23] }\end{array}$ & $\begin{array}{l}O-\text { HIS161:N[3.42] } \\
O-H I S 161: N[3.72]\end{array}$ \\
\hline 29 & $\begin{array}{l}\mathrm{NH}-\mathrm{GLY} 113: O[3.60] \\
\mathrm{NH}-\mathrm{GLY} 113: \mathrm{N}[3.45]\end{array}$ & $\begin{array}{l}C \text { - VAL171[3.49] } \\
C \text { - ILE196[3.63] } \\
C \text { - GLU115[3.68] }\end{array}$ & None \\
\hline 30 & $\begin{array}{l}\mathrm{NH}-\mathrm{GLY} 135: \mathrm{O}[2.15] \\
\mathrm{NH}-\mathrm{VAL} 136: \mathrm{N}[3.46]\end{array}$ & $\begin{array}{l}\text { C - PHE140[3.48] } \\
\text { C - TYR138[3.69] } \\
\text { C - THR132[3.67] }\end{array}$ & None \\
\hline
\end{tabular}

Helioxanthin analog 1-8 consisted of 1 hydrogen bond i.e. $\mathrm{H}$ of ligand bonds with the $\mathrm{N}$ of LYS142 with a distance of $3.79^{\circ} \mathrm{A}$. It showed 5 hydrophobic interactions i.e. C of ligand interacts with VAL136, TYR138, GLY172, ARG174 and PHE140 with the distances of $3.09^{\circ} \mathrm{A}, 3.45^{\circ} \mathrm{A}, 3.30^{\circ} \mathrm{A} 3.29^{\circ} \mathrm{A}$ and $3.28^{\circ} \mathrm{A}$, respectively.

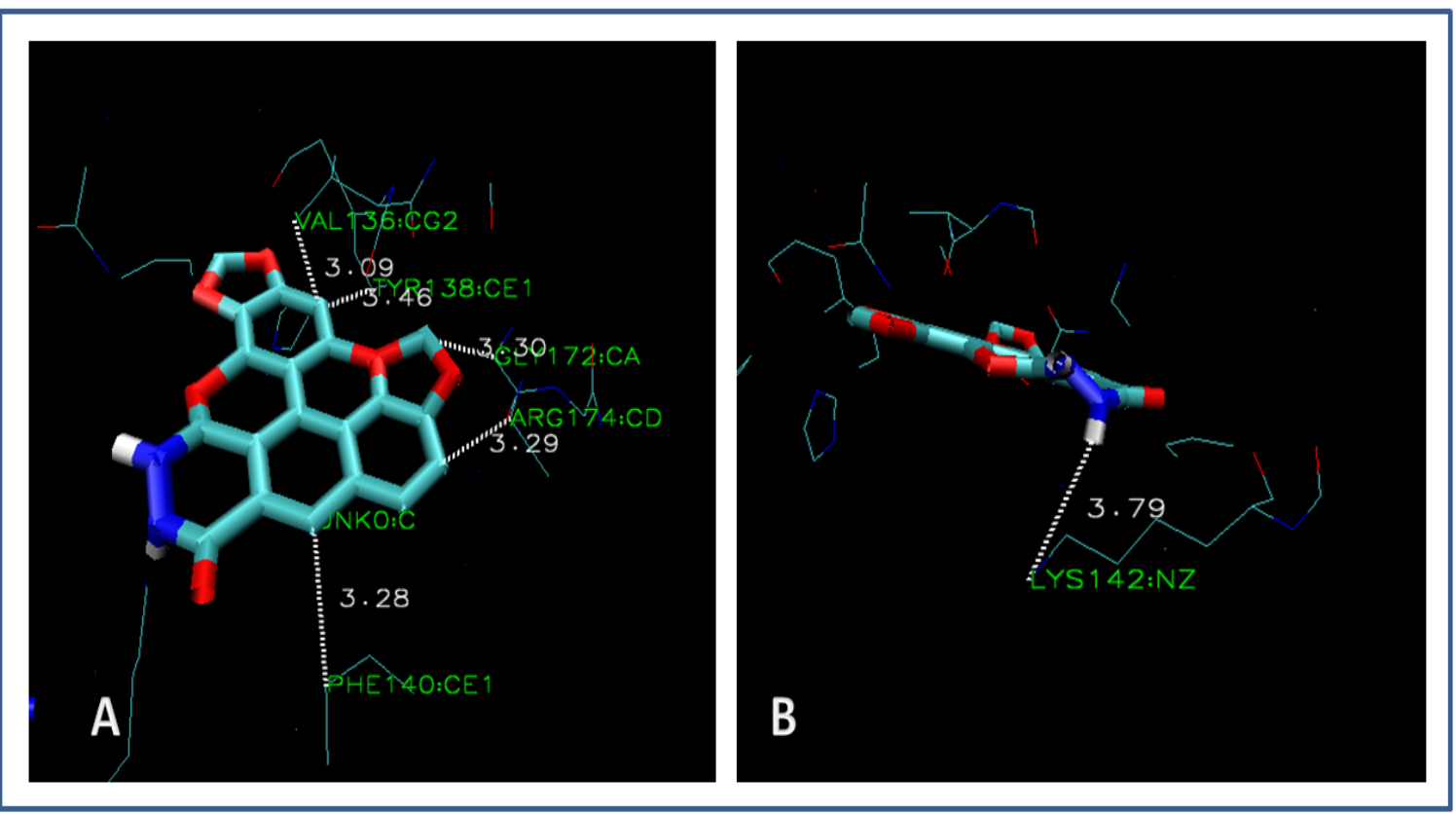


Figure 5 (A) Predicted hydrogen bond interactions of lead compound with the active site of GIPC2. (B) Predicted hydrophobic interactions of lead compound with the active site of GIPC2.

\subsection{Analog designing}

Three analogs were made of the lead compound, in order to get the possible active compounds to be used as anti-hepatitis B agent. These were designed for the lead compound by altering its chemical structure using the strategy so that its effectivity is not disturbed. The first analog was designed using the N-methylation, the second by ketone reduction and the third by using alcohol formation in the structure of lead compound.

All the analogs were docked within the active site of GIPC2 and VMD was used to get the interactions of these analogs. The analogs of lead compound with their structures were made by using ChemDraw, and their binding interactions are shown in Table 4.

Table 4. Binding interactions of analogs with amino acids of target protein present within $5^{\circ} \mathrm{A}$ radius.

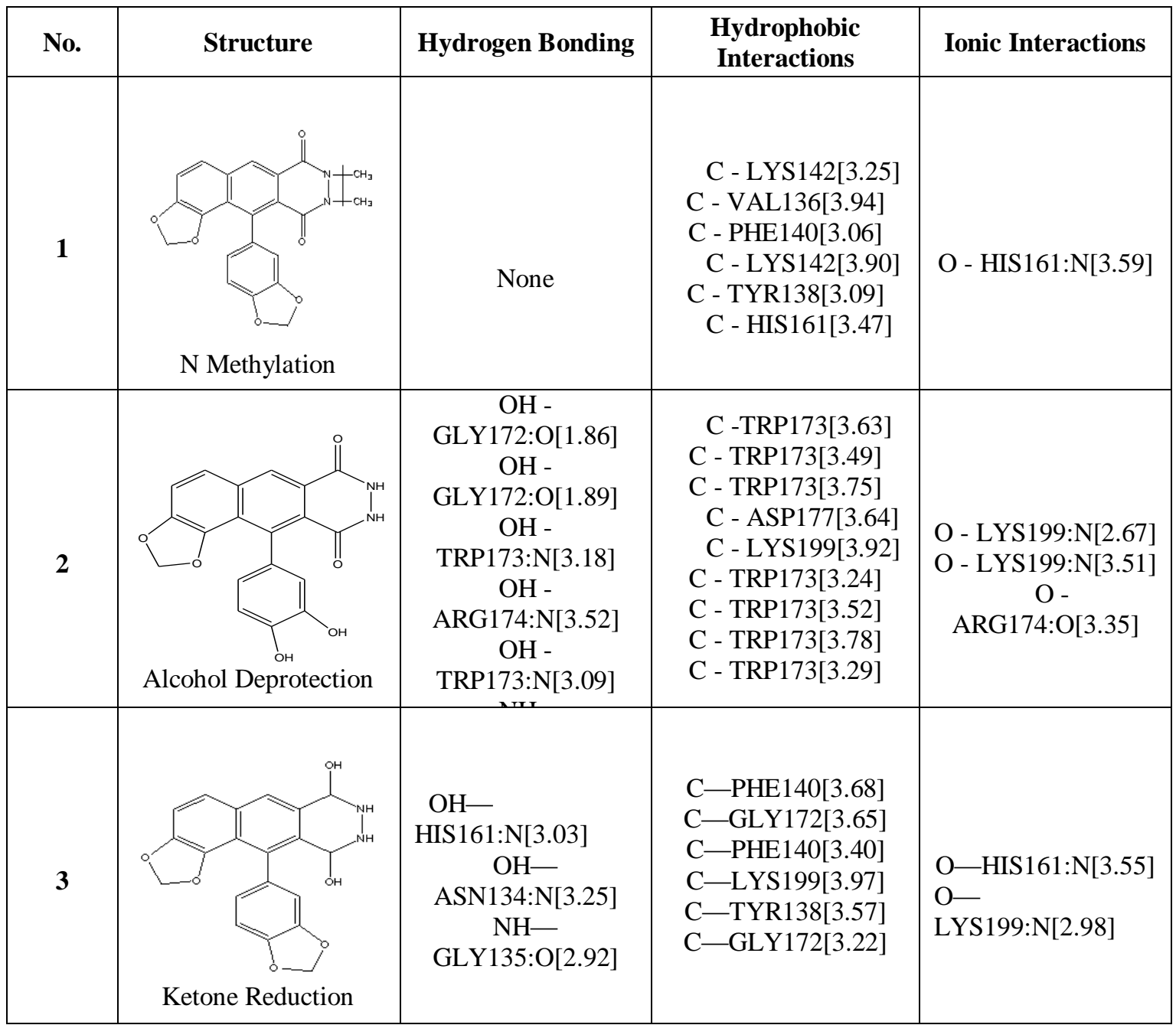

On the basis of binding interactions the analogs were categorized for being the active ligands. Analogue 2 amongst all was the most active one so it was regarded as the best one, then analog 3 and analog 1 were placed respectively. In case of 1 st analog which is made by N-methylation of the lead compound 0 hydrogen, 6 hydrophobic and 1 ionic interactions were found. 2nd analog made by alcohol formation of lead compound comprised of 9 hydrogen, 9 hydrophobic and 3 ionic interactions and the 3rd analog formed by ketone reduction of lead compound comprised of 3 hydrogen, 6 hydrophobic, and 2 ionic interactions.

\subsection{Establishing QSAR (Quantitative Structure Activity Relationship)}

QSAR studies were performed on the data of 30 compounds. For deciding why some compounds show sign of activity and others do not, QSAR model was built and a set of descriptors were chosen. These were 
assumed to influence whether a given compound will succeed or fail in binding to a given target. The descriptors of the data of the ligands chosen for QSAR studies included steric descriptors molar refractivity (MR) and hydrophobicity (LogP), and electronic descriptors Total binding energy of the ligand (ETOTAL), highest occupied molecular orbital energy (EHOMO) and lowest unoccupied molecular orbital energy (ELUMO).

These descriptors were calculated using software HyperChem and ChemDraw. The values of the calculated electronic descriptors including ETOTAL, EHOMO and ELUMO and the values of calculated steric descriptors including MR and LogP were illustrated in Table 5. In order to check the correlation of the ligand's activity with the chosen descriptor, each calculated descriptor was plotted against the IC50 value of the ligands shown in Fig.6.

Coefficient of determination (R2) was obtained for each regression plot. The regression value of electronic descriptors, ETOTAL, EHOMO and ELUMO were 0.043, 0.018 and 0.006 respectively.Results suggested that there was no significant correlation between these descriptors with the activity i.e. $R<0.6$. This in turn suggested that the activity of the drug was not dependent on a single descriptor, but on more than one descriptors and then we would have to maximize that particular descriptors in the drug for enhancing the drug's activity. In future this may act as a significant factor in drug discovery.

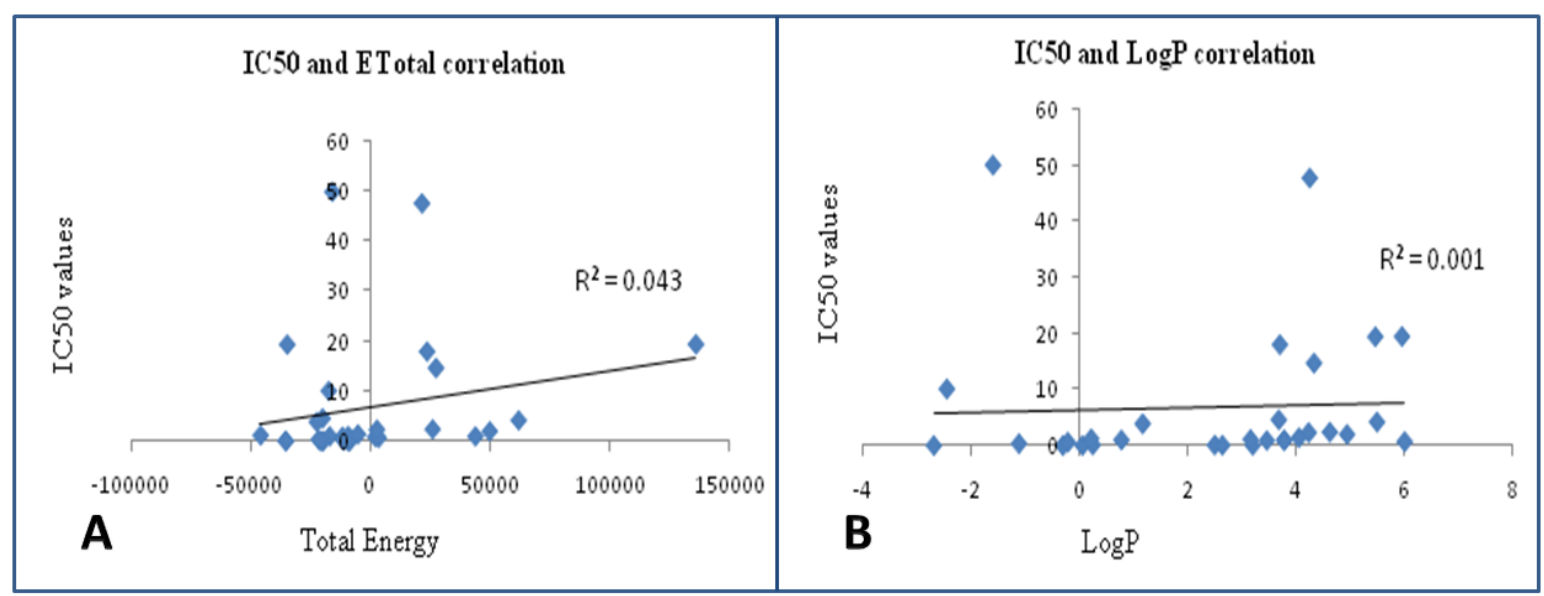

Figure 6 (A) Plot of half inhibitory concentration (IC50) and Total Energy. (B) Plot of half inhibitory concentration (IC50) and hydrophobicity. 
In silico Molecular Docking and Design of Anti-Hepatitis B Drugs

Table 5. Data set of selected Electronic and Steric descriptors.

\begin{tabular}{|c|c|c|c|c|c|}
\hline \multirow[b]{2}{*}{ No. } & \multicolumn{3}{|c|}{ Electronic Descriptors } & \multicolumn{2}{|c|}{ Steric Descriptors } \\
\hline & $\begin{array}{c}\text { EHOMO } \\
\text { (Kcal.mol-1) }\end{array}$ & $\begin{array}{c}\text { ELUMO } \\
\text { (Kcal.mol-1) }\end{array}$ & $\begin{array}{c}\text { ETOTAL } \\
\text { (Kcal.mol-1) }\end{array}$ & $\log P$ & MR \\
\hline 1 & -0.158313 & 4.575708 & -17308.3490648 & 3.78 & 95.86 \\
\hline 2 & -4.954335 & 11.608835 & -35758.0021727 & 2.5 & 101.21 \\
\hline 3 & -2.876109 & 4.850623 & -9667.9846838 & 2.64 & 95.87 \\
\hline 4 & -30.012424 & 15.477427 & 135801.6925880 & 5.95 & 138.87 \\
\hline 5 & -2.681842 & 4.636010 & -35530.5224781 & 3.2 & 93.34 \\
\hline 6 & -17.891441 & 17.458249 & 43608.8070325 & 0.78 & 79.44 \\
\hline 7 & -13.499267 & 0.908870 & 27130.0347020 & 3.87 & 119.71 \\
\hline 8 & -4.080595 & 4.488969 & -20940.8071110 & -0.3 & 55.3 \\
\hline 9 & -12.172444 & 2.941264 & 1722.6928611 & 3.46 & 62.9 \\
\hline 10 & -24.292296 & 10.022671 & -16184.5905289 & -1.59 & 57.6 \\
\hline 11 & -4.900796 & 1.750995 & 23394.5115929 & 3.7 & 119.84 \\
\hline 12 & -27.628985 & 20.098344 & -9095.3413140 & -2.68 & 65.25 \\
\hline 13 & -3.803404 & 3.018488 & -20021.1489392 & 0.06 & 55.55 \\
\hline 14 & -8.591313 & 4.738473 & -11946.7946717 & 3.78 & 94.41 \\
\hline 15 & -11.069081 & 2.120245 & -21877.6881579 & -1.11 & 56.06 \\
\hline 16 & -5.181457 & 0.729165 & -8775.5552703 & -0.21 & 63.05 \\
\hline 17 & -5.258603 & 13.925785 & -9642.1710933 & 3.16 & 43.2 \\
\hline 18 & -3.935778 & 1.182323 & -11454.5973193 & 0.25 & 35.32 \\
\hline 19 & -33.255549 & 26.179097 & 25745.1392950 & 4.62 & 114.77 \\
\hline 20 & -6.280791 & 0.893349 & 49579.2857690 & 4.94 & 120.26 \\
\hline 21 & -10.718403 & 17.576385 & 61718.3243121 & 5.49 & 128.48 \\
\hline 22 & -1.857767 & 1.257194 & 21277.6136138 & 4.25 & 112.49 \\
\hline 23 & -28.025655 & 11.098467 & 3177.9672956 & 6 & 124.8 \\
\hline 24 & -0.367562 & 2.933049 & -35041.6885674 & 5.46 & 118.69 \\
\hline 25 & -12.690814 & 15.437406 & -20245.1955527 & 3.68 & 80.56 \\
\hline 26 & -1.775271 & 5.266412 & -46146.3880020 & 0.22 & 81.39 \\
\hline 27 & -33.338975 & 17.928623 & -17681.7168374 & -2.44 & 38.88 \\
\hline 28 & -21.529241 & 10.390643 & -22686.4412304 & 1.17 & 44.63 \\
\hline 29 & -3.189464 & 2.398629 & 2421.7461061 & 4.23 & 121.55 \\
\hline 30 & -1.739376 & 6.884469 & -5466.8359632 & 4.05 & 122.53 \\
\hline
\end{tabular}

\section{Conclusion}

The present study was aimed at finding novel drug molecules as anti-hepatitis B compounds. The studies included identification of anti HBV compounds including standard compounds and their molecular docking studies with the active site of GIPC2 target protein. Ligands were found having better energy scores and interactions and a lead compound was identified. The novel analogs of the lead compound, having anti hepatitis B activity, were also suggested. 
Quantitative structure activity relationship was established in order to find the dependency trend in anti-hepatitis B activity with number of molecular descriptors and some suggestive correlation of activity with theses descriptors. It suggested that for enhancing activity of drug, particular descriptors have to be maximized. Although many QSAR studies have been carried out previously on several anti HBV compounds but the current study, on the antiviral activity of these compounds against Hepatitis B, is unique in nature [16]. This kind of computational approach will help in adding up a new antiviral agent in the list, extracted from the existing drugs. It will help in improving efficacies of the drugs and in combating the problem of resistance acquired by the virus. The compounds suggested can provide valuable information for continued search, discovery and design of novel potent antiviral agents against hepatitis B.

\section{References}

[1] W. Jia, Y. Liu, W. Li, Y. Liu, D. Zhang, P. Zhang and P. Gong, Synthesis and in vitro anti-hepatitis B virus activity of 6H[1]benzothiopyrano[4,3-b]quinolin-9-ols,Bioorganic \& Medicinal Chemistry, 17, 2009, pp. 4569-4574.

[2] G.L. Colombo, G.B. Gaeta, M. Vigano and S.D. Matteo, A cost-effectiveness analysis of different therapies in patients with chronic hepatitis B in Italy, Clinico Economics and Outcomes Research, 3, 2011, pp. 37-46.

[3] M. Ali, M. Idrees, L. Ali, A. Hussain, I.U. Rehman, S. Saleem, S. Afzal and S. Butt, Hepatitis B virus in Pakistan: A systematic review of prevalence, risk factors, awareness status and genotypes, Virology Journal, 8, 2011, pp. 102.

[4] D. Ganem and A.M. Prince, Mechanisms of disease: Hepatitis B virus infection-Natural history and clinical consequences, N. Engl. J. Med., 350, 2004, pp. 1118-1129.

[5] A. Ascherio, S.M. Zhang, M.A. Hernan, M.J. Olek, P.M. Coplan, K. Brodovicz and A.M. Walker, Hepatitis B vaccination and the risk of multiple sclerosis, N. Engl. J. Med., 344, 2011, pp. 327-332.

[6] H. Kwon and A.S. Lok, Hepatitis B therapy, Nat. Rev. Gastroenterol. Hepatol, 8, 2011, pp. 275-284.

[7] S.B. Robert, Long-term data on current treatments for chronic hepatitis B, Gastroenterology \&Hepatology, 7, 2011 , pp. 3.

[8] G.V. Papatheodoridis, Treatment of HBeAg-negative chronic hepatitis B patients with nucleos(t)ide analogues, Liver International, 31, 2011, pp. 95-103.

[9] C.M. Song, S.J. Lim and J.C. Tong, Recent advances in computer-aided drug design, Briefings in Bioinformatics Advance Access, 10, 2009, pp. 579-591.

[10] J.S. Bader and D. Chandler, Computer simulation study of the mean forces between ferrous and ferric ions in water, Phys. Chem. 96, 1992, pp. 6423-6427.

[11] F. Perveen, R. Qureshi, F.L. Ansari, S. Kalsoom and S. Ahmed, Investigations of drug-DNA interactions using molecular docking, cyclic voltammetry and UV-Vis spectroscopy, Journal of Molecular Structure, 1004, 2011, pp. 67-73.

[12] T.J.A. Ewing, S. Makino, A.G. Skillman and I.D. Kuntz, DOCK 4.0: search strategies for automated molecular docking of flexible molecule databases, J. Comput. Aided Mol. Des., 15, 2001, pp. 411-428.

[13] G.M. Morris, D.S. Goodsell, R.S. Halliday, R. Huey, W.E. Hart, R.K. Belew and A.J. Olson, Automated docking using a lamarckian genetic algorithm and empirical binding free energy function, J. Comput. Chem, 19, 1998, pp. $1639-1662$.

[14] W. Humphrey, A. Dalke and K. Schulten, VMD - Visual Molecular Dynamics, J. Mol. Graphics, 14, 1996, pp. 33-38.

[15] N. Noureen, H. Rashid and S Kalsoom, An efficient anticancer histone deacetylase inhibitor and its analogues for human HDAC8, Med. Chem. Res., 21, 2012, pp. 568-577.

[16] P.K. Arora, V.M. Patil and S.P. Gupta, A QSAR study on some series of anti-hepatitis B virus (HBV) agents, Bioinformation, 4, 2010, pp. 417-420.

[17] K.R. Cousins, "ChemDraw Ultra 9.0. CambridgeSoft, 100 CambridgePark Drive, Cambridge, MA 02140," J. Am. Chem. Soc., 127, 2005, pp. 4115-4116.

[18] J.L. Pazun, Hyperchem release 3 for windows, J. Chem. Inf. Comput. Sci. 33, 1993, pp. 931-933.

[19] N. Noureen, H. Rashid and S. Kalsoom, Identification of type-specific anticancer histone deacetylase inhibitors: road to success, CancerChemother. Pharmacol, 66, 2010, pp. 625-633.

[20] Y. Li, L. Fu, H. Yeo, J.L. Zhu, C.K. Chou, Y.H. Kou, S.F. Yeh, E. Gullen, D. Austin and Y.C. Cheng, Inhibition of hepatitis B virus gene expression and replication by helioxanthin and its derivative, Antiviral Chemistry \& Chemotherapy, 16, 2005, pp. 193201.

[21] C. Ying, Y. Li, C.H. Leung, M.D. Robek and Y.C. Cheng, Unique antiviral mechanism discovered in anti-hepatitis B virus research with a natural product analogue, PNAS., 104, 2007, pp. 120.

[22] Y.L. Zhao, G.M. Cai, X. Hong, L.M. Shan and X.H. Xiao, Anti-hepatitis B virus activities of triterpenoid saponin compound from Potentilla anserine L, Phytomedicine, 15, 2008, pp. 253-258.

[23] W.G. Yi, Z.X. Jing, Y.C. Cheng, D. Jiang, L. Zhu, Y. Liu, L. Wei, Y. Wang and H.S. Chen, Inhibition of hepatitis B virus replication by Bay 41-4109 and its association with nucleocapsid disassembly, J Chemother., 20, 2008, pp. $458-467$.

[24] A.S. Mehta, B. Gu, B. Conyers, S. Ouzounov, L. Wang, R.M. Moriarty, R.A. Dwek and T.M. Block, $\alpha$-galactosylceramide and novel synthetic glycolipids directly induce the innate host defense pathway and have direct activity against hepatitis B and C viruses, Antimicrob. Agents Chemother, 48, 2004, pp. 2085-2090.

[25] M.S. Saag, Emtricitabine, a new antiretroviral agent with activity against HIV and hepatitis B virus, Clin. Infect. Dis., 42, 2006, pp. $126-131$.

[26] Y.F. Li, G.F. Wang, P.L. He, W.G. Huang, F.H. Zhu, H.Y. Gao, W. Tang, Y. Lou, C.L. Feng, L.P. Shi, Y.D. Ren, W. Lu and J.P. Zuo, Synthesis and anti-hepatitis B virus activity of novel benzimidazole derivatives, J. Med. Chem., 49, 2006, pp. 4790-4794.

[27] W.A. Tao, L. Wu, R.G. Cooks, F. Wang, J.A. Begley and B. Lampert, Rapid enantiomeric quantification of an antiviral nucleoside agent (D,L-FMAU, 2'-Fluoro-5-methyl- $\beta$, D,L-arabinofurano- syluracil) by mass spectrometry, J.Med.Chem.,44, 2001, pp. 35413544 .

[28] W.E. Delaney, H. Yang, M.D. Miller, C.S. Gibbs and S. Xiong, Combinations of adefovir with nucleoside analogs produce additive antiviral effects against hepatitis B virus in vitro, Antimicrob. Agents Chemother, 48, 2004, pp. 103702-3710.

[29] P. Charuworn and E.B. Keeffe, A review of the use of telbivudine in the treatment of chronic hepatitis B, Clinical Medicine: Therapeutics, 1, 2009, pp. 157-166.

[30] J.M. Wu, J.S. Lin, N. Xie, F.C Jiang and K.H. Liang, Effect and mechanism of beta-L-D4A (a novel nucleoside analog) against hepatitis B virus, ZhongHuaGanZang Bing ZaZhi., 11, 2003, pp. 268-270. 
[31] W.E. Delaney, A.S. Ray, H. Yang, X. Qi, S. Xiong, Y. Zhu and M.D. Miller, Intracellular metabolism and in vitro activity of tenofovir against hepatitis B virus, Antimicrob. Agents Chemother, 50, 2006, pp. 2471-2477.

[32] P. Lu, J. Liu, Y. Wang, X. Chen, Y. Yang and R. Ji, Design, synthesis and evaluation of novel oxazaphosphorineprodrugs of 9-(2phosphonomethoxyethyl) adenine (PMEA, adefovir) as potent HBV inhibitors, Bioorganic \& Medicinal Chemistry Letters, 19, 2009, pp. 6918-6921.

[33] G.F. Wang, L.P. Shi, Y.D. Ren, Q.F. Liu, H.F. Liu, R.J. Zhang ,Z. Li , F.H. Zhu, P.L. He, W. Tang, P.Z. Tao, C. Li, W.M. Zhao and J.P. Zuo, Anti-hepatitis B virus activity of chlorogenic acid, quinic acid and caffeic acid in vivo and in vitro, Antiviral Research, 83, 2009, pp. 186-190.

[34] B. Xu, Z. Huang, C. Liu, Z. Cai, W. Pan ,P. Cao, X. Hao and G. Laing, Synthesis and anti-hepatitis B virus activities of MatijingSu derivatives, Bioorganic \& Medicinal Chemistry, 17, 2009, pp. 3118-3125.

[35] G.M. Morris, R. Huey, W. Lindstrom, M.F. Sanner, R. K. Belew, D.S. Goodsell and A.J. Olson, AutoDock4 and AutoDockTools4: Automated docking with selective receptor flexibility, J. Comput. Chem., 30, 2009, pp. 2785-2791.

[36] J. Gasteiger and M. Marsili, Iterative partial equalization of orbital electronegativity-a rapid access to atomic charges, Tetrahedron, 36, 1980, pp. 3219-3228.

[37] M. Randic, On characterization of chemical structure, Chem. Inf. Comput. Sci., 37, 1997, pp. 672-687. 